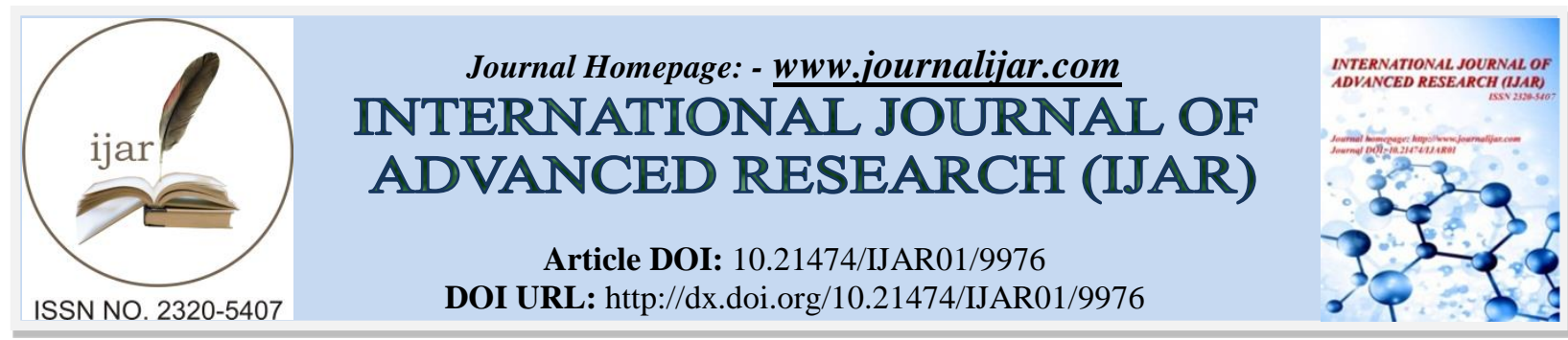

RESEARCH ARTICLE

\title{
MARKETING PERFORMANCE MEDIATES BETWEEN ICONIC PRODUCT INNOVATION AND SUSTAINABLE COMPETITIVE ADVANTAGES.
}

\author{
Muh. Hasbi Abbas ${ }^{1}$, Abd.Rahman Kadir ${ }^{2}$, Syamsu Alam ${ }^{2}$ and Madris ${ }^{2}$. \\ 1. Puangrimaggalatung University, South Sulawesi-Indonesia. \\ 2. Hasanuddin University, South Sulawesi-Indonesia.
}

\section{Manuscript Info}

Manuscript History

Received: 05 September 2019

Final Accepted: 07 October 2019

Published: November 2019

Key words:-

marketing performance, iconic product innovation, sustainable competitive advantage, SMEs of silk.

\section{Abstract}

This study focuses on Marketing Performance as a mediator between Iconic Product Innovation and Sustainable Competitive Advantage. The results showed that Iconic Product Innovation has an influence on sustainable competitive advantage, Iconic Product Innovation has no significant effect on Marketing Performance, and Iconic Product Innovation has a significant effect on sustainable competitive advantage through Marketing performance. Respondents in this study were 200 Silk SMEs located in Wajo Regency, South Sulawesi Province. Data analysis using SEM-AMOS version 23.

Copy Right, IJAR, 2019,. All rights reserved.

\section{Introduction:-}

Companies that carry out continuous innovation are seen as a source of competitive advantage. In achieving competitive advantage, there are several other things that can be a measure, namely resource excellence, position advantage, and value advantage for customers. The superiority of resources consists of superior expertise and excellence in raw materials as well as marketing and capital performance. The position superiority which consists of relatively low of cost advantages and value advantages for customers is a value that is different from the others and is not easily replaced. In accordance with Porter's opinion, competitive advantage can be obtained from resources and capital, namely the strengths and weaknesses of marketing performance, while capital is defined as the company's ability to manage its resources to work together as a work team in one department, or in other words the high or low performance of marketing will affect the high or low competitive advantage of the company. Position excellence consists of relatively low of cost advantages and value advantages for customers. In a rapidly changing environment, competitive advantage is determined by creativity and innovation that can satisfy customer desires better than competitors. Every company that competes in an industry has a competitive strategy, explicit or implicit. This strategy might be developed explicitly through the planning process or it might also have developed implicitly through the activities of various functional departments of the company.

One of the company's strategies is to create product excellence. In this study focuses on the superiority of iconic products, namely the superiority of the company by making products that become icons or symbols that serve as a reminder of consumers with the symbols contained in these products. The icon is a symbol that has a similar appearance, and the symbol is not difficult to recognize the wearer. In the icon the relationship between the representamen and the object is manifested in the same quality. The iconic model is the presentation of physical imitations as they appear on a smaller scale. The iconic model is easily observed, shaped and explained, but is difficult to manipulate and is not useful for forecasting. Iconic brand is a brand owned by consumers. Through certain understanding and experience with specific brands, consumers feel very close to the product brand and even 
feel that the brand has become a part of him. Therefore, brand owners and managers must continually look for associations that strengthen the iconic status of their brand.

\section{Competitive Advantage}

Competitive advantage as a benefit strategy of companies that collaborate to compete more effectively in a market place. The strategy must be designed to realize a competitive advantage that is continuous, so that companies can dominate the old market and new market.

In this paper, the author tries to take a product innovation approach with Iconic Products, a derivation of a symbolic dimension that has market power derived from well-known and durable local cultural symbols. Symbolic uses of iconic products are widely used to build connections and social status (Soroka and Lominadze, 2011). Indonesia with various multiethnic and multicultural backgrounds, can develop products from the interaction of members of the multi-ethnic and multicultural community so that a product has the opportunity to choose certain foreign cultural elements and domestic cultures as icons of origin (Ferdinand and Fitriani, 2016). Iconic product excellence is the level of activity of a product attribute that has a symbolic strength of the local culture that has different values and is difficult to imitate.

Holt (2004) states there are four key elements to creating an iconic brand, namely: a) Product performance must at least be accepted, preferably with good quality. b) A meaningful cultural story created by people. This must be seen as something that is legitimate and respected by consumers for the stories they receive. c) Several types of discrepancies between prevailing and hidden ideologies arise in society. In other word there are differences in how consumers consume and how they have expectations. d) Actively involved in the process of making myths, ensuring the brand maintains its position as an icon.

Product superiority is product superiority that is different from competitors. Study (McNally 2010) that product innovation excellence has a significant effect on business performance. In the product design process, the company is trying to create anything interesting about its products, producing a kind of iconic attributes that have the potential to attract potential customers. Ferdinand and Fitriani (2016) with the attractiveness of iconic acculturative products can influence marketing performance. Hsieh, et al 2008; Leonidou (2011) product excellence with the value of innovation through product design, other attributes and product quality can improve company performance.

To measure competitive advantage in this study using the Competitive Advantage Approach with the Blue Ocean Approach from Kim and Mauborge (2005) states that market competition is compared to two oceans namely the red ocean (Red Ocean) and the blue ocean (blue ocean), while the red ocean is a market space that is its limits in the industry are known and competition rules are known. Blue ocean is the creation of market space without any competitors, so competition or competition is irrelevant because of the rules of the game to be formed. Hayers and Schmenner (1978) identified five dimensions of competitive priority, namely: 1) Price, 2) Quality, 3) Dependability, 4) Product Flexibility and 5) Volume Flexibility.

Based on the literature above, the hypotheses developed are:

H1: Iconic Product Innovation (IPI) has a significant positive effect on sustainable competitive advantage (SCA).

\section{Iconic Product Innovation (IPI)}

The concept of Resource-Advantage Theory (Shelby D Hunt \& Morgan, 1995) that a good product development capability will increase the superiority of local products. Increasing the product will increase the power of market penetration (Huang \& Huddlestone, 2009) which will ultimately increase marketing performance.

An encouraging design approach to study new product development has shown that market push and pull technology do not separate, because each successful new product is based on improvements in both technological performance and semantic features, which together maintain new products to act to produce new meanings.

\section{Iconic Product Innovation Indicators}

Measurement of innovation to find out which company is oriented towards high or low levels innovation. This innovation orientation is measured by whether companies often introduce new products, new services, new production processes, product quality and raw materials. The more companies introduce new products, the company 
means that the level of innovation orientation is higher. The more often companies improve new services the better the level of innovation orientation. Production processes, product quality and raw material quality also determine the degree of innovation orientation (Kirca, Jayachandran \& Bearden, 2005; Jhonson et al., 2009).

Iconic product innovation is the ability of organizations to adopt and implement both new ideas, processes and products that are iconic in an area. The combination of company resources and organization creates an innovation strategy for the company that influences competitive advantage over competitors and company performance. The study (Waranantakul, et al 2009) resulted in the capability of innovation to have a significant positive effect on competitive advantage. Research (Chailom and Ketchen, 2010) innovation capability has a positive effect on the company's competitive advantage. several studies also support this hypothesis (Lee and Hsieh, 2010).

\section{H2: Iconic Product Innovation (IPI) has a significant positive effect on Marketing Performance (MP)}

\section{Marketing Performance}

Techniques to maximize organizational performance in long-term business must recognize and build mutually beneficial relationships with buyers. A business that places the consumer as king in the organization means that the company wants to give more value to customers in the hope of obtaining a long-term competitive advantage, so that it can provide superior benefits (Narver \& Slater, 1990).

Marketing performance is part of organizational performance. Organizational performance consists of marketing performance, financial performance, and human resource performance. The company's strategy is always directed to produce marketing performance, namely sales volume, market share, and sales growth and marketing performance as an effort to measure the level of performance including sales turnover, number of buyers, profits and sales growth (Voss \& Voss, 2000; Ferdinand, 2006).

Empirical influence between marketing capabilities (product capabilities, price capabilities, distribution capabilities and promotional capabilities) and export performance in the context of developing countries. This research is based on empirical investigations from various foreign companies in Thailand. The results of his research indicate that products, prices and promotions have a positive and significant impact on export marketing performance (Schroeder, et al. 2002; Bilal, 2010; Kanchanda, 2011)

Performance measurement that is to measure organizational performance in small and medium-sized companies is more suitable to use a growth approach because small and medium-sized companies are generally less open in financial statements so it is difficult to interpret (Miler, 2003). Marketing performance indicators can be seen from market results, customer valuation results, customer behavior results and financial results.

Market results consist of sales (volume and value), sales to new customers, sales trends, market share (volumes and values), market trends, number of customers, number of new customers, number of new prospects, (leads generated / questions), conversions (leads to sales), Penetration, Distribution / availability, prices, relative prices (SOM value / volume), price premiums, price elasticity.

Consumer assessment results consist of brand awareness, relevance to consumers, perception of differentiation, perceived quality / price, perceived quality, image / reputation, perceived value, preferences, customer satisfaction, customer loyalty / retention, possibilities to recommend. Financial results consist of profit / profitability, shareholders gross / EVA / ROI, customer life value.

The results of customer behavior consist of customer loyalty / retention, Churn rate, Number of customer complaints, Number of transactions per customer, Share of wallet (Ambler \& Puntoni, 2003; Davidson, 1999). Then Voss and Voss (2000) Marketing performance indicators consist of meeting sales targets, number of customers, sales growth from year to year, marketing reach, profit growth. This indicator is also often used by other researchers.

Pricing decisions have become important decisions made by all business firms at all levels and have posed a major challenge for Small and Medium Enterprises in Nigeria. Research on pricing in relation to sales turnover which is one indicator of marketing performance has been conducted by Imoleayo (2010). This research uses a survey method and empirical approach, with administering questionnaires to several SMEs in Nigeria. The results suggest there is a relationship between changes in cost of goods sold and sales turnover. This study recommends that SMEs must use the services of pricing experts when making price decisions. 
In relation to the development of sales growth indicators and profit margins, Stein (2008) suggests two development models. Model 1 companies can choose to increase sales growth, or model 2 to choose to increase profit margins per unit. If a company manager cares about current stock prices, he will support a growth strategy. Conversely, if the manager cares about dividends he supports the profit margin per unit.

Marketing performance is an achievement of the company in increasing sales and profit margins. To be able to continue to grow and compete in competition is very important in modifying the business model. This is in line with research (AR Kadir, N Kamariah, NF Arif, 2019) stating that business model innovation can improve sales / marketing performance so that companies can increase their competitive advantage.

Based on the literature review above the developed hypothesis is:

H3: Iconic Product Innovation (IPI) has a significant positive effect on sustainable competitive advantage (SCA) through Marketing Performance (MP)

\section{Methodology:-}

\section{Research design}

This research is categorized as applied research that is directed at solving specific problems when the research is conducted and basic / fundamental research is directed at the development of science / theory (Sekaran 2000, 2011). This research is an exploratory study using quantitative research methods and using SEM-AMOS analysis tools.

\section{Population and sample}

The population is Silk SMEs in Wajo Regency, South Sulawesi. The sample uses purposive sampling with the type of Judgment Sampling. The sample in this study was 200 SMES.

\section{Research Model}

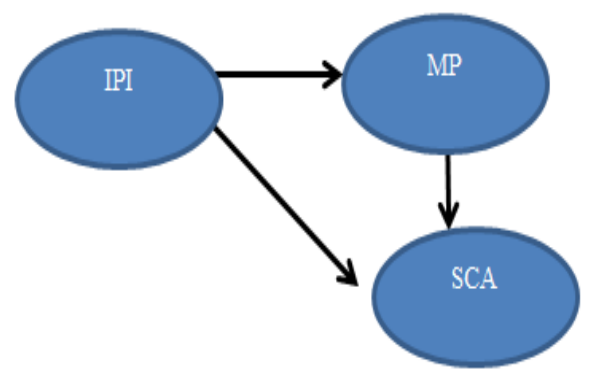

IPI: Iconic Product Innovation

MP: Marketing Performance

SCA: Sustainable Competitive Advantage

\section{Characteristics of Respondents}

The objects in this study are formal and informal SMEs in the women's sector in Wajo Regency. The distribution of places / locations of respondents is as follows (Table 1.1)

Table 1.1:-Distribution of Respondent Locations

\begin{tabular}{|c|l|c|c|}
\hline \multirow{2}{*}{ No } & \multicolumn{1}{|c|}{ Districts } & Amount & Percentage \\
\cline { 3 - 4 } & & Respondents & $(\%)$ \\
\hline 1 & Belawa & 13 & 6,5 \\
\hline 2 & Bola & 0 & 0 \\
\hline 3 & Gilireng & 0 & 0 \\
\hline 4 & Keera & 2 & 1 \\
\hline 5 & Majauleng & 30 & 15 \\
\hline 6 & Maniangpajo & 30 & 15 \\
\hline 7 & Pammana & 5 & 2,5 \\
\hline 8 & Penrang & 10 & 5 \\
\hline
\end{tabular}




\begin{tabular}{|c|l|c|c|}
\hline 9 & Pitumpanua & 10 & 5 \\
\hline 10 & Sabbangparu & 5 & 2,5 \\
\hline 11 & Sajoanging & 20 & 10 \\
\hline 12 & Takkalalla & 15 & 7,5 \\
\hline 13 & Tanasitolo & 30 & 15 \\
\hline 14 & Tempe TOTAL & 30 & 15 \\
\hline & \multicolumn{1}{|c|}{ TO0 } & $\mathbf{1 0 0}$ \\
\hline
\end{tabular}

Source: Primary data processed, $2019(\mathrm{~N}=200)$

Based on the results of research conducted on 200 respondents who are female SMEs in Wajo District, the characteristics of respondents were obtained based on gender. These characteristics can be seen in table 1.2 as follows:

Table 1.2:-Characteristics of Respondents by Gender

\begin{tabular}{|c|c|c|c|}
\hline No & Gender & Frequency & Percentage (\%) \\
\hline 1 & Male & 80 & 40 \\
\hline 2 & Female & 120 & 60 \\
\hline & TOTAL & $\mathbf{2 0 0}$ & $\mathbf{1 0 0}$ \\
\hline
\end{tabular}

Source: Primary data processed, $2019(\mathrm{~N}=200)$

\section{Results and Analysis:-}

Normality

Normality test is measured using a Critical ratio of \pm 2.58 at a significance level of $1 \%$ (0.01) (Ghozali, 2008). Based on the results of processing research data compared to these criteria, it can be concluded that the data distribution is normal, both univariate for each indicator and overall multivariate indicator

\begin{tabular}{|c|c|}
\hline Variable Indicator & Univariate \\
\hline SCA_1: Price & .766 \\
\hline SCA_2: Quality & .893 \\
\hline SCA_3 : Dependability & 2.690 \\
\hline SCA_4 : Product Flexibility & .408 \\
\hline SCA_5: Volume Flexibility & .438 \\
\hline MP_5 : Profit Growth & .568 \\
\hline MP_4 : Marketing Reach & .923 \\
\hline MP_3 : Sales Growth & 1.895 \\
\hline MP_2 : Number of customers & 1.931 \\
\hline MP_1: Sales Target & .703 \\
\hline IPI_6 : Iconic Packaging Innovation & 7.800 \\
\hline IPI_5 : Iconic Attribute Innovation & 16.940 \\
\hline IPI_4 : Symbol Design Innovations & 9.121 \\
\hline IPI_3 : Iconic Material Innovation & 7.666 \\
\hline IPI_2 : Iconic Pattern Innovation & 6.698 \\
\hline IPI_1 : Iconic innovation & 8.370 \\
\hline Multivariate & 215.297 \\
\hline
\end{tabular}

\section{Goodness of FIT}

Goodness of fit test aims to see whether the data in accordance with the model built in this study. GFI, CFI, TLI and RMSEA are benchmarks that meet the standards in this study. The model is said to be FIT with the Model if the values of GFI, CFI, TLI are more than $\geq 0.09$ and RMSEA $\leq 0.08$. The FIT models in this study are CFI $=0.928$, $\mathrm{TLI}=0.915$. 


\section{Validity test}

\begin{tabular}{|c|c|c|c|c|c|c|}
\hline & & Standardized & SFL & Error & \multirow[t]{2}{*}{$\mathbf{C R}$} & \multirow[t]{2}{*}{ AVE } \\
\hline Variabel & Indikator & Loading Factor & Kuadrat & {$[\mathbf{E j}]$} & & \\
\hline \multirow[t]{5}{*}{ IPI } & X1.1 & 0.64 & 0.410 & 0.590 & \multirow[t]{6}{*}{0.83} & \multirow[t]{6}{*}{0.50} \\
\hline & $\mathrm{X} 1.2$ & 0.776 & 0.602 & 0.398 & & \\
\hline & $\mathrm{X} 1.3$ & 0.746 & 0.557 & 0.443 & & \\
\hline & $\mathrm{X} 1.4$ & 0.784 & 0.615 & 0.385 & & \\
\hline & $\mathrm{X} 1.5$ & 0.552 & 0.3047 & 0.695 & & \\
\hline Total & & 3.498 & 2.488 & 2.512 & & \\
\hline \multirow[t]{5}{*}{$\mathrm{MP}$} & Y1.1 & 0.667 & 0.444889 & 0.555111 & \multirow[t]{6}{*}{0.82} & \multirow[t]{6}{*}{0.50} \\
\hline & Y1.2 & 0.766 & 0.586756 & 0.413244 & & \\
\hline & Y1.3 & 0.784 & 0.614656 & 0.385344 & & \\
\hline & Y1.4 & 0.753 & 0.567009 & 0.432991 & & \\
\hline & Y1.5 & 0.465 & 0.216225 & 0.783775 & & \\
\hline Total & & 3.435 & 2.429535 & 2.570465 & & \\
\hline \multirow[t]{5}{*}{$\mathrm{SCA}$} & Y2.1 & 0.997 & 0.994009 & 0.005991 & \multirow[t]{6}{*}{0.94} & \multirow[t]{6}{*}{0.76} \\
\hline & Y2.2 & 0.979 & 0.958441 & 0.041559 & & \\
\hline & Y2.3 & 0.788 & 0.620944 & 0.379056 & & \\
\hline & Y2.4 & 0.785 & 0.616225 & 0.383775 & & \\
\hline & Y2.5 & 0.773 & 0.597529 & 0.402471 & & \\
\hline Total & & 4.322 & 3.787148 & 1.212852 & & \\
\hline \multicolumn{5}{|c|}{ Acceptable limits } & $\geq 0.70$ & $\geq 0.50$ \\
\hline
\end{tabular}

H1: Iconic Product Innovation (IPI) has a positive and significant effect on Sustainable Competitive Advantage (SCA). The results showed that the Iconic Product Innovation (IPI) had a positive and significant effect on Sustainable Competitive Advantage (SCA) $(\mathrm{B}=0.080, \mathrm{P}<0.05)$. H1 Accepted

H2: Iconic Product Innovation (IPI) has a significant positive effect on Marketing Performance (MP). The results showed that Iconic Product Innovation (IPI) had no positive and significant effect on Marketing Performance (MP) $(\mathrm{B}=0.052, \mathrm{P}>0.05) . \mathrm{H} 2$ Rejected

H3: Iconic Product Innovation (IPI) has a significant positive effect on sustainable competitive advantage (SCA) through Marketing Performance (MP). The results showed from the Sobel Test statistical test that Iconic Product Innovation (IPI) had a positive and significant influence on sustainable competitive advantage (SCA) through Marketing Performance (MP) (Z-test = 3.276> 1.80). H3 Accepted.

\section{Hypothesis testing}

\begin{tabular}{|l|c|c|}
\hline \multicolumn{1}{|c|}{ Hypothesis } & Coefficient & Result \\
\hline Direct Effect & $0.080^{*}$ & Accepted \\
H1: Iconic Product Innovation (IPI) $\rightarrow$ Sustainable competitive advantage \\
(SCA)
\end{tabular}

\section{Discussion and Implications:-}

Iconic Product Innovation (IPI) has a positive and significant effect on Sustainable Competitive Advantage (SCA). These results are in line with research by Ferdinand and Fitriani, 2016, namely elements of foreign culture and certain domestic cultures as icons of origin can be an iconic product excellence which is the level of activity of a product attribute that has symbolic strength of local culture which has different values and is difficult to emulate so that it can be a competitive advantage. 
Iconic Product Innovation (IPI) does not significantly influence Marketing Performance (MP). This result is different from some previous studies where Iconic Product Innovation has a significant effect on Marketing Performance. However, this reinforces the theory of the Concept of Resource-Advantage Theory (Shelby D Hunt \& Morgan, 1995) that good product development capabilities will enhance the advantages of local products. Increasing the product will increase the power of market penetration (Huang \& Huddlestone, 2009) which will ultimately increase marketing performance. This is in line with the fact in the field that Iconic product innovation has no direct effect on marketing performance without product development capabilities. And this is what happens to the facts on the ground, although iconic products are typical of an area but are not accompanied by the ability to develop these products so it does not have any impact on marketing performance.

Iconic Product Innovation (IPI) has a positive effect on Marketing Performance (MP) through Sustainable Competitive Advantage (SCA). The results of this study are in line with the results of the Schroeder study. et al. 2002; Bilal, 2010; Kanchanda, 2011 shows that products, prices and promotions have a positive and significant impact on marketing performance. Marketing performance is an achievement of the company in increasing sales and profit margins. To be able to continue to grow and compete in competition is very important in modifying the business model. This is in line with research (AR Kadir, N Kamariah, NF Arif, 2019) stating that business model innovation can improve sales / marketing performance so that companies can increase their competitive advantage.

\section{Recommendations for Future Research}

In this study there is a gap where the results of the study differ from previous studies, namely Product Innovation has no significant effect on marketing performance. From the results of this study recommend for further researchers to examine the factors of product innovation that can improve marketing performance.

\section{References:-}

1. Agbaje, O. B. A., Wakil, S. M., \& Osowole, A. A. (2014). Synthesis, Spectroscopic Characterization and Antimicrobial Activities of Some Mixed Drug Metal (II) Complexes of Sulfamethoxazole and Paracetamol. Oluwatoosin B. A. Agbaje, Sherifat M. Wakil and Aderoju A. Osowole, 2014. https://doi.org/10.5171/2014

2. Arif, N. F. (2014). Critical Success Factor Dalam Adopsi E-Commerce Di Makassar Sulawesi Selatan. Jurnal Economix, 5(2), 20-31.

3. Conference, I. (2019). Advances in Economics, Business and Management Research (AEBMR), volume 92 3rd International Conference on Accounting, Management and Economics 2018 (ICAME 2018), 92(Icame 2018), $42-48$.

4. Fan, R., Chang, K., Hsieh, C., Wang, X., \& Lin, C. (2008). : A Library for Large Linear Classi cation. Corpus, 9, 1871-1874. https://doi.org/10.1038/oby.2011.351

5. Ferdinand, A. (2006). Pengembangan Minat Beli Merek Ekstensi. Badan Penerbit Unviersitas Diponegoro.

6. Fitriani, L. K., \& Ferdinand, A. T. (2015). Acculturative Iconic Product Attractiveness and Marketing Performance. Journal of Global Strategic Management, 2(9), 15-15. https://doi.org/10.20460/jgsm.2015915570

7. Foxe, J. J., Wylie, G. R., Martinez, A., Schroeder, C. E., Javitt, D. C., Guilfoyle, D., ... Murray, M. M. (2002). Auditory-somatosensory multisensory processing in auditory association cortex: An fMRI study. Journal of Neurophysiology, 88(1), 540-543. https://doi.org/10.1152/jn.2002.88.1.540

8. Hunt, S. D., \& M.Morgan, R. (1995). R-a Theory-Jm95.Pdf. Journal of Marketing.

9. Indriastuti, H., Nugroho, B., \& Aryanto, V. D. W. (2017). Small and medium enterprises' product benchmarking advantages on marketing performance. International Journal of Mechanical Engineering and Technology, 8(7), 70-84.

10. Johannesen, E., Hvingel, C., Aschan, M., \& Bogstad, B. (2007). Survey based estimation of consumption: spatial and seasonal aspects of cod predation on shrimp. NAFA SCR Document.

11. Kim, W. C., \& Mauborgne, R. (2005). Value innovation: A leap into the blue ocean. Journal of Business Strategy, 26(4), 22-28. https://doi.org/10.1108/02756660510608521

12. Kirca, A. H., Jayachandran, S., \& Bearden, W. O. (2005). Market Orientation: A Meta-Analytic Review and Assessment of its Antecedents and Impact on Performance. Journal of Marketing. https://doi.org/10.1509/jmkg.69.2.24.60761

13. Kompetensi, P., Manufaktur, B., Strategi, D. A. N., Terhadap, B., Manufaktur, P., \& Indonesia, D. I. (2005). Pengaruh kompetensi bidang manufaktur dan strategi bisnis terhadap kinerja perusahaan manufaktur di indonesia, 7(2), 17-33.

14. Leonidou, L. C., Leonidou, C. N., Palihawadana, D., \& Hultman, M. (2011). Evaluating the green advertising practices of international firms: A trend analysis. Studies in Economics and Finance, 28(1), 6-33. 
https://doi.org/10.1108/02651331111107080

15. Malberg, H., Wessel, N., Hasart, A., Osterziel, K. J., \& Voss, A. (2002). Advanced analysis of spontaneous baroreflex sensitivity, blood pressure and heart rate variability in patients with dilated cardiomyopathy. Clinical Science, 102(4), 465-473. https://doi.org/10.1042/CS20010106

16. Massa, S., \& Testa, S. (2012). The role of ideology in brand strategy: The case of a food retail company in Italy. International Journal of Retail and Distribution Management, 40(2), 109-127. https://doi.org/10.1108/09590551211201865

17. Miler, M. (2003). Holographic Gaussian to flat-top beam shaping. Optical Engineering. https://doi.org/10.1117/1.1613956

18. Narver, J. C., \& Slater, S. F. (1990). The Effect of a Market Orienttion on Business Profitablitly. Journal of Marketing.

19. Neumar, R. W., Otto, C. W., Link, M. S., Kronick, S. L., Shuster, M., Callaway, C. W., ... Morrison, L. J. (2010). Part 8: Adult advanced cardiovascular life support: 2010 American Heart Association Guidelines for Cardiopulmonary Resuscitation and Emergency Cardiovascular Care. Circulation, 122(SUPPL. 3). https://doi.org/10.1161/CIRCULATIONAHA.110.970988

20. Rauret, G., López-Sánchez, J. F., Sahuquillo, A., Rubio, R., Davidson, C., Ure, A., \& Quevauviller, P. (1999). Improvement of the BCR three step sequential extraction procedure prior to the certification of new sediment and soil reference materials. Journal of Environmental Monitoring, 1(1), 57-61. https://doi.org/10.1039/a807854h

21. Sekaran 2000. (2011). Information needs and Information seeking behaviors of Social Science Graduate Students in Malaysian Public Universities. International Journal of Business and Social Science.

22. Soroka, Ekaterina, and Tea Lominadze. (n.d.).

23. Voss, R. S., \& Jansa, S. A. (2003). Phylogenetic Studies On Didelphid Marsupials Ii. Nonmolecular Data And New Irbp Sequences: Separate And Combined Analyses Of Didelphine Relationships With Denser Taxon Sampling. Bulletin of the American Museum of Natural History. https://doi.org/10.1206/00030090(2003)276<0001:psodmi>2.0.co;2

24. Wu, C. C., Lin, D. W., Keshavarzi, A., Huang, C. H., Chan, C. T., Tseng, C. H., ... Mii, Y. J. (2010). High performance 22/20nm FinFET CMOS devices with advanced high-K/metal gate scheme. Technical Digest International Electron Devices Meeting, IEDM, 600-603. https://doi.org/10.1109/IEDM.2010.5703430 